\title{
The status of Belinuropsis wigudensis Matthew, 1910, a Pennsylvanian merostome from New Brunswick, Canada
}

\author{
Randall F. Miller \\ Steinhammer Palaeontology Laboratory, New Brunswick Museum, \\ 277 Douglas Avenue, Saint John, New Brunswick E2K 1E5, Canada
}

Date Received June 29, 1995

Date Accepted July 5, 1995

\begin{abstract}
Fossils comprising the type specimen of the merostome Belinuropsis wigudensis Matthew, 1910 have been located in the New Brunswick Museum collection. The specimens raise questions concerning the validity of the monotypic genus Belinuropsis.

Des fossiles comprenant le spécimen type de mérostome Belinuropsis wigudensis Matthew, 1910, ont été trouvés dans la collection du Musée du Nouveau-Brunswick. Les spécimens soulèvent des questions au sujet de la validité du genre monotypique Belinuropsis.
\end{abstract}

[Traduit par la rédaction]

\section{INTRODUCTION}

The merostome Belinuropsis wigudensis Matthew has appeared in palaeontological literature occasionally (Stormer, 1979; Selden and Siveter, 1987) since its original description in the 1909 Transactions of the Royal Society of Canada (Matthew, 1910). The monotypic genus Belinuropsis Matthew, 1910, was listed in Størmer (1979, p. P41) and placed in incertae sedis. The type specimen has been inaccessible for decades, and its reported age is incorrect. Matthew (1910) believed the Fern Ledges-Duck Cove locality in Saint John, New Brunswick to be Silurian in age (Stopes, 1914), an interpretation followed by Størmer (1979). The section is now known to be Pennsylvanian, Westphalian B, Cumberland Group, Lancaster Formation (Williams et al., 1985). Two specimens matching Matthew's illustration of $B$. wigudensis have been located in the New Brunswick Museum palaeontology collection and assigned catalogue numbers NBMG 3307 and NBMG 3308 (Miller, 1988). Examination of the specimens casts doubt on validity of the genus erected by Matthew.

\section{Discussion}

Belinuropsis wigudensis was described as a "crustacean of the general type of Belinurus" (Matthew, 1910, p. 116) with differences sufficient to warrant a new genus. Matthew's description and illustration (Matthew, 1910, p. 127, plate 1, fig. 3a-d) suggest a single specimen was the basis for this new genus; however, the illustration, reproduced in Stormer $(1979$, p. 15, fig. 11-8), is based on a composite of two specimens, NBMG 3307 and 3308 that cannot be re-assembled as a single unit as presented by Matthew. Although Matthew credits two collectors, A.G. Leavitt and W. McIntosh, each piece was labelled as having been collected by a different person, and it is possible they were collected on separate occasions.
The original labels do not identify either specimen as $B$. wigudensis and suggest Matthew originaly intended to describe NBMG 3307 as a new species of Belinurus.

NBMG 3307 (prosoma) label - "spider fragment of the body inner surface of test Duck Cove A.G.L. '06 Dadox. sandst. Bed 2" and a second label "Belinurus (?) Leavitti, n.sp. Bed 2. Dadox sand."

NBMG 3308 (opisthosoma) label - "typ Spider? Belinurus parts of body underside of part of abdomen \& detached spines surface minutely punctate $\&$ with scattered tubercules; joints grooved Dadox. Duck Cove St. John Co, N.B. Coll. W. McIntosh."

Much of the arthropod material from the "Fern Ledges" site is poorly preserved and difficult to interpret. Recent examination of NBMG 3307 and 3308 reveals few details that would permit placement beyond possibly being eurypterid(?) cuticle (W. Shear, personal communication, 1994). In view of the poor quality and the nature of the specimens designated as the types, Belinuropsis wigudensis should be considered a nomen dubium. Neither fossil comprising Matthew's Belinuropsis wigudensis is well enough preserved to warrant a new description.

\section{ACKNOWLedgements}

Thanks to W. Shear, Hampden Sydney College, for comments on arthropod fossils from the "Fern Ledges" site.

Matthew, G.F. 1910 (1909). Remarkable forms of the Little River Group. Transactions of the Royal Society of Canada, 3, pp. 115-133. 
Miller, R.F. 1988. Catalogue of Type Fossils in the New Brunswick Museum. New Brunswick Museum Publications in Natural Science, Number 7,75 p.

Selden, P.A. and Siveter, D.J. 1987. The Status of Bellinuroopsis Chernyshev, 1933, and Neobelinuropsis Eller, 1938 (Xiphosura, Bellinuroidea). Journal of Paleontology, 61, p. 1285.

Stopes, M.C. 1914. The "Fern Ledges" Carboniferous flora of St. John, New Brunswick. Canada Department of Mines, Geological Survey, Memoir 41, 142 p.
Størmer, L. 1979. Merostomata. In Treatise on Invertebrate Paleontology, Part P Arthropoda 2. Edited by R.C. Moore. Geological Society of America and University of Kansas Press, Lawrence, pp. P4-P41.

Williams, G.L., Fyffe, L.R., Wardle, R.J., Colman-Sadd, S.P., and Boenner, R.C. 1985. Lexicon of Canadian Stratigraphy, Volume VI, Atlantic Region. Canadian Society of Petroleum Geologists, Calgary, 572 p.

Editorial Responsibility: R.K. Pickerill 